\title{
THE IMPACT OF EFFICIENT MANAGEMENT MECHANISM OF THE ENERGY SUPPLY ON ENVIRONMENT
}

\author{
Vadim Chekalin \\ St. Petersburg State University \\ of Engineering and Economics, Russia
}

\begin{abstract}
An economic growth of the country strongly depends on the terms and level of development of key economic sectors, including energy supply. The centralized heat supply plays considerable role at energy sector of Russian economics. Privatization and economic liberalization in the Russian Federation have generated relations between the economic subjects which differ a lot from Soviet Union system. However, the centralized heat supply system means of heat tariffs formation were inherited from Soviet Union and they still apply practically without changes.

It is necessary to pay attention also to an ecological component of this problem. Nowadays, if we want to preserve environment for the future and eliminate negative consequences, we should spend much more financial and technological resources. The result of negative impact of applying out-of-date energy technologies characterized by low efficiency can be enhancement of environmental contamination: water, air, soil.

Working out of theoretical, practical and organizational and economic principles for formation of the state tools management in a centralized heat supply sphere, enhancement of efficiency at the present stage must be the subjects of research works. The complex solution of problems of the market organizational and economic management mechanism is complicated because of lack of methodological, methodical information for authority at all hierarchical levels. Therefore working out in this very important sector should become one of priority tasks.
\end{abstract}

\section{KEYWORDS}

Energy sector, centralized heat supply sphere, organizational and economic principles, ecological and economical efficiency, impact on environment.

\section{INTRODUCTION}

Energy complex of cities consists of systems and structures necessary for its survival. This complex has a significant impact on the environment of the city and adjacent territories.

Power engineering are worn out and need to be updated. On average, worn of boiler has reached $55 \%$, of public heating $-63-65 \%$, of electrical networks $-58 \%$. Industrial energy situation in a more favourable, but the use of energy systems in many cases, also weak. Applied technology largely outdated and requires deep modernization or full update. In many cities there is a scarcity of energy resources. Efficient management of energy enterprises is https://doi.org/10.15626/Eco-Tech.2010.077 
not established. Energy facilities have a low level of reliability, they are characterized by great loss of energy, especially thermal energy.

Some of the reasons for this situation include: lack of investment, higher energy consumption (in 2-3 times higher than in Europe), the high cost of production, excessive monopoly, the absence of a mechanism to promote resource conservation, etc. But all production, transfer and use of energy is related to the impact on the ecology of megalopolis.

In cities of Russia energy system formed without taking into account the negative impact of production processes, the transfer and use of energy on the environmental characteristics and not far from acceptable sanitary and hygienic requirements.

\section{ALTERNATIVE SOURCES OF ENERGY}

Hence the need to find alternative sources of energy. Consider the possibility of using alternative energy, which is often said that enthusiastically.

The hypothesis that there are alternative, clean and cheap energy sources, based on the fact that people generally show only a single item ènergoproizvodâsej chain, not the beginning and not the end. In the case of alternative tehnolologiâmi their supporters often remain silent about the disadvantages of using them.

The first one. Methods of storage and transmission of electricity are far from perfect. They required a powerful grids (LEP), which you can bring to each site (a process that is destructive to the environment through which transmission takes place) or batteries. The most robust and long-lived batteries now made of lead and sulfuric acid. The production of both ecologically grâzen, these elements are dangerous to human health, and economically viable recycling processes old rechargeable batteries has yet to be invented, so they are simply thrown in the dustbin. These are general negative points whenever you use electricity.

The second. Hydroelectric power station. Require huge reservoirs, zabolačivaûsih ground over large areas and completely changing environment, not to mention the name type flooded cellars and rassypaûsihihsâ foundations. Often destroyed valuable forest reserve, with an undercurrent of infestations kills all life in the area.

The third. Hydrogen fuel. First, its production requires electricity. Secondly, the safe and efficient transport and storage of hydrogen has to be invented. He is extremely volatile, liquefied gas as it is very easy and explodes, and low temperature (-253 degrees Celsius) destroys material make hydrogen containers.

The fourth. Solar power. First, with solar panels-exactly the same problems with lead batteries: toxic chemical compounds, production, and lack of effective methods of recycling. Secondly, the intensive drainage of energy (heat) from soil surfaces would lead to an overall cooling, which in turn will cause changes to winds, rainfall, the negative effects on flora and fauna, etc., with constant sunshine (deserts) are usually not easily accessible in terms of transporting energy generated there.

Wind power. First, not invented wind pumps with high efficiency. Secondly, the widespread use of "windmills" changing the winds and rainfall that also has a negative impact on the local environment.

Tidal. The same: and rotting of water near the shoreline.

The seventh. Geothermal energy plants. They are located in seismically unstable and areas remote from civilisation, stretching from power line is difficult and expensive.

\section{IMPRUVEMENT OF HEAT SUPPLY SISTEMS IN CITIES OF RUSSIA}

A key link in cities is the system of heating. Estimated to be $25-35 \%$ of all energy of Russia is spent on heating, the loss of $30 \%$ (in developed countries is around $2 \%$ ), and $45-70 \%$ of heat demand repair or replacement. 
Serving urban district heating system is not effective, technologically outdated and in need of renovation, but it requires huge resources

Therefore the task of reconstruction of the heat supply system of the city could not be solved in the traditional way on the basis of a centralized budgeting Development of heat supply system, perhaps through the creation of effective economic mechanism based on a modern regulatory framework, clear guarantees to investors and new financing methods.

In modern conditions it can be investments (loans, funds, including foreign) and domestic sources of energy. Energy savings shall be carried out by both producers and consumers. Strategic approach is an effective alternative to the budget. Its essence is a coherent coordination of all stakeholders and the creation of an effective energy heat supply system of the city. Coordinated design, production, transportation, innovation, investment, operation and use of energy. Develop and implement a strategy is needed to improve the efficiency of heat supply of the city by introducing advanced technologies and modern management.

Thrust strategy consists in improving systems of heat supply through the introduction of advanced technologies and adequate governance.

Main tasks:

- ensuring consumers in thermal resources;

- ensuring reliable operation of heating systems;

- introduction of energy saving technologies;

- formation of effective system of management of heating and energy conservation.

But the implementation of the strategy linked to a number of barriers to be overcome:

- lack of funds from the city to finance energy efficiency projects.

- lack of resources in the energy industries and the difficulty in attracting long-term credits

- weak energy consumption management, i.e. lack of skills among many managers and professionals.

All these points make it difficult, but does not exclude the possibility of a strategic approach to the development of this complex

So can only be achieved through the establishment of an effective system of economic relations between all parties to the energy process, for example, in the form of a performance contract the ESCO. Main participants:

- City Administration- support energy guarantees to investors, enterprises, the adoption of programmes and projects and preparation of regulatory energy;

- Committee on fares-tariff policies, tariff harmonization between project.

- Manager company project-elaboration and realization of project management, coordination of all actors involved, the regulation of financial flows of the project.

The heating of residential and industrial premises very timely in our country where the average heating season reaches six months a year. Millions of people are employed in the industry providing country heat and hot water. Not meeting this requirement would prevent a country in today's globalized world.

In USSR the efficiency of district heating has been very little attention. And just in the last decade, with the introduction of a market economy and the rising cost of heat, began to research on improving the efficiency of district heating.

Russia has the potential to save energy equal to the annual energy consumption in France. Experts came to the conclusion of the International Finance Corporation (IFC) and the World Bank in the course of study "energy efficiency in Russia: the hidden reserve. the greatest potential for energy savings provide energy consumption of residential buildings $(49 \%$ of 
total energy consumption), industry (38\%), the budget sphere, including housing and communal services $(42 \%)$. the reserve increase energy efficiency exists virtually.

Obstacles to the use of energy-efficient solutions are not only related to legislation, issues of funding and lack of effective motivation management but also to a lack of awareness of stakeholders on the potential for energy savings. According to another study by IFC, enterprise managers evaluate the potential for energy savings at $8-10 \%$, whereas experience shows that this figure is $35-40 \%$.

In addition, IFC and World Bank analysts point out the problem of introduction of energy efficiency policies, not for the Russian economy as a whole, but for specific industries. For example, the barriers inherent in the budgetary sphere, associated with the inability to dispose of the savings generated by energy savings: budgetary institutions deprived of the right to retain and use that money. They are denied the right to enter into long-term contracts or contracts with the return of investment of future savings, and procurement practices in this area is based on the lowest price rather than a minimum-cost over the lifetime of objects.

The problem of introduction of energy-saving measures in the energy sector are associated with an emphasis on construction of new generating capacity, rather than the efficiency. The methodology regarding tariffs does not promote operational efficiency. The study puts emphasis on the need to reform the way tariff, providing financial incentives.

Reserves increased efficiency of heat supply in Russia:

- reduced loss of heat during transportation;

- substantial reductions in consumption of electric energy on network pumps;

- heat energy consumption reduction by applying automatic day/night and eliminate peretopov "on $25-40 \%$;

- lowering the cost of the construction and renovation of district heating networks, at $25-50 \%$.

Failure to use this potential industry employing millions of citizens, harms the entire economy of the State. Does not allow you to create high competitive products for sale to overseas, lowers the level of people's lives.

Let's pay attention to the environmental dimension of the problem. If we now "Save" to save the environment, in the future to address the negative effects of us will have to spend much more money. A main focus in improving the environmental performance of energy systems is the use of improved technologies and maximise energy savings during the generation, transportation and energy consumption.

Industrial power engineering, including district heating is adverse impact of mankind on the environment. Everything on Earth, with or without a human, and nature of activity gives rise to opposition. The man is a product of nature. It is also present in all the works of human hands. Impact suffered in the past century, the natural habitat, including industry, an extremely high.

Quite a large group of followers technological scientizma binds soil contamination, water, forest dieback, reduction of the ozone layer not only with the result of the work, but also with the imperfections of nature itself, which has a number of fundamental flaws. Therefore, withdrawal from the environmental crisis is associated with the ecological production, designed to improve and refine the nature, i.e. the option to create an artificial environment is proposed to replace the failed promise of "human nature. The contentious nature of this view is:

-in the absence of proof to the imperfections of nature to those of the people -the risk that delicate balance still exists in nature as a result of ecological production, 
-the likelihood of more rapid adjustment to the artificial environment of organisms harmful to human life: viruses, bacteria, etc.

-that there is no way to accurately predict and evaluate the possible effects of active ecological production.

Another point of view can be considered a more balanced, which stems from the awareness of the need

-preserving and maintaining the existing environment,

-acceptance of the inevitability of scientific and technological progress, but the drive in the direction of perfection of resource-saving and low-waste technology, maximum preserving nature.

The advantages of this approach is modern researchers the negative effects of development technosphere and, for the person who can take even irreversible. Increasingly, they are seen in the developments of heredity, DNA mutations, permanent overloads his organism and psyche. The industry-heating, of course, must evaluate their influence on the environment, as far as possible to minimize it (put in water treatment technology, etc.) and make up for sciencebased activities. A very important area to address environmental problems are finding ways to generate alternative forms of energy. But there is a traditional centralized heat supply should, whenever possible, it is not only economic, but also to reduce the impact on the environment. Having such a great effect on the existence of modern heating systems in Russia, the industry has become established, and the role of the State in this industry is really great. Indirect confirmation of this is that for more than 15 years, domestic heating has the ability to apply state-of-the-art engineering design but domestic heating system as a whole did not become effective.

Development of organizational and economic bases for the formation of centralized management tools from heat, increasing the efficiency of an industry is the focus of economic science. But complex solution of organizational-economic mechanism of heat-supply industry is hampered by the lack of adequate training and information. Primary action are: binding an objective instrument accounting application multi-stage of tariffs, as an instrument to stimulate modernization of engineering networks, the establishment of the State system of reporting on the effectiveness of designing effective investments in the improvement of the budgetary funds for district heating and others.

\section{CONCLUSIONS}

1. Over the past 15-20 years there have been significant changes in the economic and legal relations in the energy systems of Russia.

2. Russia had to conform to modern standards in all of the energy systems, including heating.

3. Domestic industry supply, due to climatic and technological peculiarities, had a significant impact on the environment and quality of life for citizens.

4. Effectively for, the State is obliged to establish effective instruments to encourage improved industry: tariffs, accounting, pricing.

\section{REFERENCES}

Kuznik I.V. The centralized heat supply. We design efficiency. - M.: Publishing house MEI, 2008. -156p. 